\title{
Aroma retention during drying of caja-umbu fruit pulp
}

Fontes, A. S. ${ }^{a}$; Leite-Neta, M. T. S. ${ }^{a}$; Matos, P. N. ${ }^{a}$; Araujo, H. C. S. ${ }^{a}$; Jesus, S. M..$^{a}$; Rajkumar, G. ${ }^{\text {a; }}$ Narain, N. $^{{ }^{*}}$

aLaboratory of Flavor and Chromatographic Analysis, Federal University of Sergipe, Av. Marechal Rondon, s/n, Jardim Rosa Elze, 49100-000, São Cristóvão, SE, Brazil

*E-mail of the corresponding author: narendra.narain@gmail.com

\begin{abstract}
This study was aimed to obtain and characterize the dried powder of cajáumbu (Spondias spp) fruit pulp obtained by spray-drying and lyophilization. Spray-drying of the pulp was done at different temperatures. Analysis of bioactive compounds and volatile compounds was performed. The total phenolic compounds content was high in the dried powder obtained at the temperature of $140{ }^{\circ} \mathrm{C}$. The volatiles analysis of dried powders revealed that the powder dried at $140^{\circ} \mathrm{C}$ contained a larger number of compounds. The cajá-umbu powder showed that it is a better alternative for storage and conservation since it retained the majority of volatile compounds.
\end{abstract}

Keywords: Cajá-umbu, volatile compounds, gas chromatography, mass spectrometry. 


\section{Introduction}

Aroma is an important characteristic in exotic tropical fruits, which has increasingly attracted consumers due to their peculiar sensorial attributes. Brazil is one of the countries that have a large variety of these fruits, which are usually produced widely and are mostly consumed in fresh form or in the form of juices, ice cream, jams and jellies. Among the large variety of tropical fruits grown mainly in the Brazilian northeast region, fruits belonging to the genus Spondias, involving umbu (Spondias tuberosa Arruda Camara), yellow mombin (Spondias mombin L.), cajá-umbu (Spondias spp), purple mombin (Spondias purpurea L.) and amberella (Spondias dulcis L. syn. Spondias cytherea Sonn.) are prominent. The volatile composition of these fruits pertain to several chemical classes, such as tannins, terpenoids (sesquiterpenes and monoterpenes), flavonoids, etc. ${ }^{[1,2]}$

The cajá-umbu (Spondias spp.) owing to its particular sensorial characteristics, such as aroma and flavor, is a fruit which is very much appreciated in the northeastern region of Brazil. It is native to the semi-arid regions and is cultivated between the states of Rio Grande do Norte, Ceará, Piauí, Pernambuco and Bahia. Its sensorial characteristics possessing strong acidic exotic aroma and attractive color, make this fruit to be highly demanding in the regions of the country where it is found. ${ }^{[3,4,5]}$

Being a climacteric fruit, the shelf life of cajá-umbu fruit is low and thus it is commercialized in the near by places where it is produced. It is therefore a great challenge to transport and commercialize this fruit to places far from its cultivation. In order to preserve this fruit and to develop new products with increased commercial value, dehydration techniques such as freeze drying and spray drying can be used.

To the best of the author's knowledge no studies have been performed until the present moment on drying of cajá-umbu fruit and also to identify volatile and bioactive compounds in cajá-umbu dehydrated by these two techniques of drying. Thus the objective of this study was to evaluate the effect of two drying processes - freeze-drying and spray-drying of cajáumbu pulp (Spondias spp) on the retention of volatile and bioactive compounds.

\section{Materials and Methods}

\subsection{Fruit purchase and pulp extraction}

The ripe mature fruits of cajá-umbu were acquired from the Center of Supply (CEASA) of the city of Aracaju/SE. These were then taken to the Laboratory of Processing of Vegetable Origin, located in the Department of Food Technology at the Federal University of Sergipe (UFS). The selected fruits were submitted to selection, sanitization pulping and packaging in polyethylene packages. 


\subsection{Spray Drying}

For the Spray dryer process, experiments were performed by varying the drying air temperature $\left(100,120,140\right.$ and $\left.160^{\circ} \mathrm{C}\right)$ while maltodextrin concentration was maintained at $15 \%$. The atomization was performed in a spray dryer with a nozzle atomization system of the brand LABMAQ (model MSDi 1.0, Brazil) with injector nozzle having $1.2 \mathrm{~mm}$ diameter orifice, air flow of $4.00 \mathrm{~m} / 3 \mathrm{~min}$ and pressure of air of $4 \mathrm{kgf} / \mathrm{cm}^{2}$. The spray dryer was fed through a peristaltic pump, with rotation speed adjusted as a function of the maximum speed; this flow being $0.52 \mathrm{~L} / \mathrm{h}$. The dried powder was stored in glass containers with a screw cap, then sealed and stored in a desiccator at room temperature $\left(25 \pm 2{ }^{\circ} \mathrm{C}\right)$.

\subsection{Lyophilization}

The drying of pulp was also performed in a Christ Freeze Dryer, (model Alpha 1-4 LSC, Germany). The pressure used was 0.42 mbar, at a sublimation temperature within the chamber was $-58^{\circ} \mathrm{C}$.

\subsection{Separation and Identification of Volatile Compounds}

The volatile compounds were captured through the purge and trap system (Tekmar Mark, Model ATOMX), using the Vocarb3000 trap and analyzed in the gas chromatography system coupled to a mass spectrometer (GC- QqQ MS, Agilent 7000) according to the method with adaptations reported by Narain et al. ${ }^{[5]}$ The volatile compounds were analyzed in GC-MS system using a Carbowax column (30 m x $0.25 \mathrm{~mm} \times 0.25 \mu \mathrm{m})$. The oven temperature was programmed: initiation at $35^{\circ} \mathrm{C}$ (held for $2 \mathrm{~min}$ ) then raised at a rate of $10^{\circ} \mathrm{C}$ to $100^{\circ} \mathrm{C}$ (held for $1 \mathrm{~min}$ ) and finally increased at $3^{\circ} \mathrm{C} / \mathrm{min}$ to $250^{\circ} \mathrm{C}$. Volatile compounds were tentatively or positively identified by comparing their mass spectra with the compounds from NIST (National Institute of Standards \& Technology) database and comparing the linear retention index (LRI) of the standards and compounds with those of literature publications and other databases (Flavornet, PubChem, Pherobase).

\section{Results and Discussion}

\subsection{Volatile compounds of dehydrated powder}

Dehydration reduces the moisture content and therefore can result in the loss of volatile compounds in the final product at the end of the process. ${ }^{[6]}$ Studies on the influence of temperature are very important to guarantee the quality of the final dehydrated product. ${ }^{[7]}$ When developing a powder obtained by spray drying or lyophilization it is necessary to always standardize the best temperature where a powder can be obtained with the aroma very close to that of the fresh fruit. Thus, it is important to study the volatile composition of the product obtained by dehydration at various temperatures in order to define the best condition for obtaining an aromatic product at the end of the process. 
In the Table 1 presents the data on number of peaks obtained on the analysis of dried powders obtained at different temperatures used for spray drying and by lyophilization. The volatiles analysis of dried powders revealed that the spray dried product at $140^{\circ} \mathrm{C}$ contained higher number (29) of compounds, compared to lyophilization which had only 26 compounds.

Table 1: Number of volatile compounds found in various dried powders obtained by
\begin{tabular}{ccc} 
spray and freeze & drying of cajá-umbu pulp. \\
\hline Dehydration type & Temperature & Number of peaks \\
\hline Spray-drying & $100^{\circ} \mathrm{C}$ & 18 \\
Spray-drying & $120^{\circ} \mathrm{C}$ & 20 \\
Spray-drying & $140^{\circ} \mathrm{C}$ & 29 \\
Spray-drying & $160^{\circ} \mathrm{C}$ & 19 \\
Lyophilization & $-58^{\circ} \mathrm{C}$ & 26
\end{tabular}

The most representative class of compounds for the dried powders obtained by atomization were the terpenes, and the compound with the highest concentration was limonene at all the operating temperatures of the Spray-dryer (Table 2). Other terpenes identified were $\alpha$ pinene, cis- $\alpha$-bisabolene, 3-carene, $\beta$-pinene, $m$-xylene. Narain et al. ${ }^{[5]}$ reported the presence of these compounds in ripe cajá-umbu (Spondias sp) fruit pulp when the extraction was performed by the Purge \& Trap extraction technique and compounds were separated by using Carbo-WAX column and identified in a GC-MS system.

Tong Chin et al. ${ }^{[8]}$ studied the influence of the temperature on the retention capacity of the volatile compounds markers of the atomized durian pulp and monitored the propanethiol and ethyl propanoate compounds at two temperatures of $170^{\circ} \mathrm{C}$ and $130^{\circ} \mathrm{C}$, and reported that at a temperature of $170^{\circ} \mathrm{C}$ a reduction in the number of volatile compounds occurred. In the present work as seen in Table 1, the temperature at which a higher number of peaks was obtained and also a higher intensity was observed was at $140^{\circ} \mathrm{C}$. At this temperature it is also possible to detect the appearance of compounds which at other temperatures were not found, for example, 3-carene, $m$-xylene while there was an increase in the concentration of the esters such as ethyl acetate, ethyl butanoate and ethyl lactate.

The use of high temperatures can also lead to the formation of new compounds in dehydrated products. Gozales-Palomare et al. ${ }^{[9]}$ working with dehydrated powder of Hibiscus sabdariffa at temperatures of $150,160,170,180,190,200$ and $210^{\circ} \mathrm{C}$ reported the formation of furfuraldehyde in the dehydrated product at temperatures of $180-210^{\circ} \mathrm{C}$. Similar results were found for dehydrated cajá-umbu powders at temperatures of 140 and $160^{\circ} \mathrm{C}$, being higher in $160^{\circ} \mathrm{C}$. According to Nunes et al. ${ }^{[10]}$, the presence of furfural in ODG is probably expected as heating increases ascorbic acid degradation. Therefore, furfural analysis could be used to monitor product quality during guava drying processes as it may be considered as a marker of heating. 
Table 2: Volatile compounds present in dried powder of cajá-umbu pulp

\begin{tabular}{|c|c|c|c|c|c|c|}
\hline \multirow{2}{*}{ Compound } & \multirow{2}{*}{ LRI $_{\text {Lit }}$} & \multicolumn{4}{|c|}{ Dried powder-Spray drying } & \multirow{2}{*}{ FDP } \\
\hline & & $100^{\circ} \mathrm{C}$ & $160^{\circ} \mathrm{C}$ & $140^{\circ} \mathrm{C}$ & $120^{\circ} \mathrm{C}$ & \\
\hline Ethanal & 724 & 0.322 & 3.007 & & 2.188 & \\
\hline Pentanal & 935 & & 0.544 & 0.674 & & \\
\hline Verbenone & & & & 1.837 & & \\
\hline Furfural & 1455 & & 2.64 & 0.415 & & \\
\hline Acetone & & 1.966 & 1.727 & 2.396 & 2.524 & \\
\hline $\begin{array}{l}\text { 3-Methyl-4-propenyl-oxetan } \\
\text {-2-one }\end{array}$ & & & 0.21 & & 0.129 & \\
\hline Ethyl acetate & 907 & 1.841 & 1.104 & 2.181 & 2.007 & \\
\hline Ethyl lactate & & & & & & 16.964 \\
\hline Ethyl butanoate & 1037 & 1.92 & & 0.695 & 0.431 & \\
\hline Prenylacetate & & 0.696 & & 0.586 & 0.38 & \\
\hline Propyl butanoate & & & & & & 8.432 \\
\hline Ethyl isovalerate & 1100 & & & & & 1.039 \\
\hline Ethyl octanoate & 1436 & & & & & 0.265 \\
\hline Pyrrole & 915 & & & & & 6.248 \\
\hline$m$-xylene & 1150 & & & 0.461 & & \\
\hline 3,4-Dimethyl styrene & & 0.145 & & 0.606 & 0.129 & \\
\hline Ethanol & 932 & 4.212 & 3.95 & 9.914 & 3.919 & \\
\hline$\delta$-Octalactone & & & & & & 2.054 \\
\hline$\delta$-Nonalactone & & & & & & 1.239 \\
\hline 3-Aminobutanoic acid & & & & & & 4.627 \\
\hline$\alpha$-Pinene & 1030 & 0.644 & 0.577 & 3.934 & 0.604 & \\
\hline 1R- $\alpha$-Pinene & 1055 & & & & & 6.22 \\
\hline (Z) Hydrated sabinene & 1123 & & & & & 0.354 \\
\hline 3-Carene & 1148 & & & 0.116 & & 0.237 \\
\hline 1,3,8-p-Menthatriene & 1158 & & 0.082 & 1.606 & & \\
\hline$\beta$-Pinene & 1138 & 0.129 & 0.114 & 0.843 & 0.519 & \\
\hline$\alpha$-Terpinene & 1178 & & & & & 5.001 \\
\hline Limonene & 1177 & 18.92 & 16.759 & 15.797 & 19.37 & \\
\hline$(+)$-Limonene & 1201 & & & & & 18.714 \\
\hline Cyclofenchene & & & & & & 4.628 \\
\hline cis- $\beta$-Ocimene & 1234 & & & 0.463 & & \\
\hline Ocimene & 1225 & & & & & 4.852 \\
\hline o-Cymene & 1261 & 0.322 & 0.49 & 1.277 & 0.355 & \\
\hline (E)- $\beta$-Ocimene & 1242 & & & & & 1.557 \\
\hline Copaene & 1488 & & & & & 0.68 \\
\hline Alloaromadendrene & 1599 & 17.35 & 18.704 & 10.537 & 16.67 & \\
\hline Isocaryophyllene & 1570 & & & & & 2.588 \\
\hline cis- $\alpha$-bisabolene & 1543 & 1.317 & 1.789 & 0.824 & 1.319 & \\
\hline $\begin{array}{l}\text { (3Z)-2,7-Dimethyl-3-octen } \\
\text {-5-yne }\end{array}$ & & 0.309 & 0.207 & 0.955 & 0.27 & \\
\hline
\end{tabular}

* LRI - Linear Retention Index; FDP - Freezed dried powder 
An interesting factor to be emphasized is the higher presence of esters in the cajá-umbu pulp powder obtained by freeze-drying than in powder obtained by spray-drying. Compounds such as ethyl lactate (16.96\%), which possesses a mild odor and propyl butanoate (8.432\%) characterized by a fruity odor, were found in significant concentrations. Tietel et al. ${ }^{[11]}$ studying the changes in concentrations of volatile compounds of tangerine reported that a slight increase in temperature caused a decrease in the concentration of esters such as ethyl acetate, ethyl butanoate, ethyl hexanoate. Similar behavior was observed in this study when compared to the lyophilization technique that uses low temperatures, when compared with the spray-drying technique that uses high temperatures.

Another aspect that probably influenced a lower retention of esters in the spray-drying was the retention capacity of the wall material in relation to these compounds. Rosenberg et al. ${ }^{[12]}$ studying the factors that affect ester retention in the spray-drying technique observed that these compounds are not readily retained in the carrier material with a concentration of less than $30 \%$. For the dehydrated cajá-umbu pulp, a similar behavior was observed to that reported by Rosenberg et. al. ${ }^{[12]}$ since the carrier material (maltodextrin) concentration was $15 \%$, thus not resulting in a better retention of the esters.

\section{Conclusions}

The pulp dehydration in the spray dryer maintained the nutritional and organoleptic characteristics of the fresh pulp resulting in a promising product for marketing purposes. In the identification of the volatile composition of the dried powders, 29 compounds were identified in the spray-drying process at $140^{\circ} \mathrm{C}$ and 26 compounds in the dehydrated powder by lyophilization. However, the major compound identified was limonene in both dehydration techniques. At all temperatures $\left(100,120,140\right.$ and $\left.160^{\circ} \mathrm{C}\right)$ of dehydration tested by spray drying, the highest number of volatile compounds were identified in the dried powder at a temperature of $140^{\circ} \mathrm{C}$. Thus, it is concluded that the optimum dehydration temperature of the cajá-umbu pulp by the spray-drying process is $140^{\circ} \mathrm{C}$.

\section{References}

[1] Lima, E.Q.; Ferreira, C.F.S.L.; Oliveira, E.; Costa, V.C.O.; Dantas M.K.L. Phytochemical characterization of Spondias sp and Spondias tuberosa Arruda Câmera extracts of occurrence in Paraiba semiarid. Journal of Experimental Biology and Agricultural Sciences, 2017, 5 (5), 713-717.

[2] Galvão, M.S.; Narain, N.; Santos, M.S.P.; Nunes, M.L. Volatile compounds and descriptive odor attributes in umbu (Spondias tuberosa) fruits during maturation. Food Research International, 2011, 44, 1919-1926.

[3] Lima, E.D.P.A.; Lima, C.A.A; Aldrigue, M.L.; Gondim, P.S. Caracterização física e química dos frutos da umbu-cajazeira (Spondias spp.) em cinco estádios de maturação, 
da polpa e néctar. Revista Brasileira de Fruticultura. Jaboticabal, 2002, 24 (2), 338343.

[4] Santos, D.C.; Rocha, A.P.T.; Gomes, J.P.; Oliveira, E.N.A.; Albuquerque, E.M.B.; Araujo, G.T. Storage of 'umbu-cajá' pulp powder produced by lyophilization. Revista Brasileira de Engenharia Agrícola e Ambiental, 2016, 20 (12), 1118-1123.

[5] Narain, N.; Galvão, M.S.; Madruga, S.M. Volatile compounds captured through purge and trap technique in cajá-umbu (Spondias spp.) fruits during maturation. Food Chemistry, 2007, 102, 726-731.

[6] Phoungchandang, S.; Saentaweesuk, S. Effect of two stage, tray and heat pump assisted dehumidified drying on drying characteristics and qualities of dried ginger. Food and Bioproducts Processing, 2010, 89, 429-437.

[7] Gogus, F.; Ozel, M.Z.; Lewis, A.C. The effect of various drying techniques on apricot volatiles analysed using direct thermal desorption-GC-TOF/MS. Talanta, 2007, 73, 321-325.

[8] Tong Chin, S.; Nazimah, S.A.H.; Quek, S.Y.; Man, Y.B.C.; Rahman, R.A.; Hashim, D.M. Changes of volatiles' attribute in durian pulp during freeze- and spray-drying process, 2008, 41, 1899-1905.

[9] Gonzalez-Palomares, S.; Estarrón-Espinosa, M.; Gómez-Leyva, J.F.; AndradeGonzález, I. Effect of the temperature on the spray drying of Roselle extracts (Hibiscus sabdariffa L.) Plant Foods for Human Nutrition, 2009, 64 (1), 62-67.

[10] Nunes, J.C.; Lago, M.G.; Castelo-Branco, V.N.; Oliveira, F.R.; Torres, A.G.; Perrone, D.; Monteiro, M. Effect of drying method on volatile compounds, phenolic profile and antioxidant capacity of guava powders. Food Chemistry, 2016, 197, 881-890.

[11] Tietel, Z.; Lewinsohn, E.; Fallik, E.; Porat, R. Importance of storage temperatures in maintaining flavor and quality of mandarins. Postharvest Biology and Technology, 2012, 64, 175-182.

[12] Rosenberg, M.; Kopelman, J.; Talmon, Y. Factors affecting retention in spray-drying microencapsulation of volatile materials. Journal of Agricultural and Food Chemistry, 1990, 38, 1288-1294. 